\title{
Ethnobotanical Study of the Mexican Laurel in El Chico National Park, Mexico: A Quantitative Perspective
}

\author{
Daniela Ortega-Meza ${ }^{1 *}$, María Teresa Pulido-Silva ${ }^{1}$, Joari Costa de Arruda ${ }^{2}$, and Carolina Joana da Silva ${ }^{2}$ \\ ${ }^{1}$ Instituto de Ciencias Básicas e Ingeniería, Centro de Investigaciones Biológicas, Universidad Autónoma del Estado de \\ Hidalgo, Pachuca de Soto, Hidalgo, Mexico. ${ }^{2}$ Centro de Estudos em Limnologia, Biodiversidade e Etnobiologia do Pantanal, \\ Universidade do Estado de Mato Grosso, Cáceres, Mato Grosso, Brazil. \\ *labetnobiologiauaeh@gmail.com
}

\begin{abstract}
This study was conducted in two villages of El Chico National Park (ECNP), Mexico, to document the uses of Litsea glaucescens (Mexican laurel) by the local population and to identify actors with knowledge about the species using quantitative ethnobotanical techniques. Fifty-five semi-structured interviews were conducted to obtain a free-list about the specific uses of the laurel, to analyze its importance among the social group under study, and to use social networking to identify individuals within the community who had particular knowledge about the plant. We found a total of 25 specific uses for the plant, which have different levels of importance for the people of the ECNP. The most common use was seasoning, while medicinal and cultural uses had a lesser importance. Use of the seed of the laurel as a material for handcrafts is recorded for the first time in this study. The social network showed that there was a relationship between the actors interviewed from the two communities. They are identified as having some relationship to the plant or knowledge about it, but the actors who produce it are the most prominent. An analysis of the specific uses of the laurel and those with knowledge about it is considered indispensable for generating specific management and harvesting strategies for the species, which will be able to contribute a local perspective to its conservation.
\end{abstract}

Received October 19, 2018

OPEN ठACCESS

Accepted January 29, 2019

DOI 10.14237/ebl.10.1.2019.1427

Published April 15, 2019

Keywords Free-list, Natural Protected Area (NPA), Quantitative ethnobotany, Social network, Mexican laurel

Copyright (c) 2019 by the author(s); licensee Society of Ethnobiology. This is an open-access article distributed under the terms of the Creative Commons Attribution-NonCommercial 4.0 International Public License (https://creativecommons.org/licenses/by-nc/4.0), which permits non-commercial use, distribution, and reproduction in any medium, provided the original author and source are credited.

\section{Introduction}

The success of human populations has depended in part on their knowledge and manipulation of their environment, an aspect in which plants play a fundamental role (Pardo de Santayana and Gómez 2003). Several researchers have studied the importance of plants to rural communities: how the plants are managed, their diverse uses, and the best conservation methods. However, special attention should be given to the uses of species in Natural Protected Areas (NPAs), as in most cases conservation in protected areas does not take into account the cultural contexts in which these uses have evolved (Tuxill and Nabhan 2001).

Ethnobotany has clear applications to conservation science in several aspects. It is fundamental for identifying the diversity of plants used by humans and understanding how local people select, use, and manage plants, and why (Gaoue et al. 2017), and documenting the knowledge that human populations have about them. This type of knowledge should be applied in conservation, since it provides real and functional information on the use and management of useful species and vegetation as a whole (Shrestha and Medley 2017). This information could be used to generate public policy and by decision makers and policy makers (Albuquerque et al. 2009). This applies mainly to species with economic and cultural importance (including symbolic importance) that contribute to human welfare (Albuquerque et al. 2009). Ethnobotany also enables the necessary tools to be generated to promote sustainable use of plant resources (Gómez-Pompa 2001; López-Gutiérrez et al. 2014; Pío-León et al. 2017). Additionally, ethnobotany research potentially 
encourages conservation from an etic and emic perspective (Pío-León et al. 2017).

In Mexico, a variety of plants are used by communities residing within NPAs (Pulido and Cuevas-Cardona 2013). These plants provide multiple benefits, as they are grown not only for commerce, but also for daily household use (Alexiades and Shanley 2004). However, there are few NPA management plans that address the conservation of plants that are considered useful or valuable either because of their subsistence value or because of their ceremonial and social importance (Tuxill and Nabhan 2001). The value and importance of useful plants can be classified according to their contribution within the traditional culture of a given human group and can be evaluated from two perspectives. The first is to determine the number of useful plants in a location overall, and the second is to learn the actual or potential applications of a given plant (Turner 1988).

There are a number of methods for determining the importance of different species or families of plants. These methods include quantitative techniques; for example, measuring cultural significance through the use of indices (Turner 1988), relative importance and use value (Phillips and Gentry 1993), or the importance of a given use based on its frequency and the order in which it is mentioned, as is the case of Smith's salience index (Borgatti 1996).

These methods have enabled the relationship between people and plants to be investigated effectively. However, in order to understand the importance of a species from the local perspective, it is also necessary to understand the relationship between the members of the human groups studied, who are the users of these resources. Social networks are useful for locating information about the capacity for intercommunication and organization among the members of a group, as well as for finding out individual actors' perceptions of other members and their own positions within the group (Boster et al. 1987).

This study evaluates the importance of specific uses of Mexican laurel (Litsea glaucescens) in two communities (villages) in ECNP. The Mexican laurel grows wild in the Abies religiosa ("oyamel") forest of this natural protected area and has been classified as in danger of extinction under the Mexican NOM-059SEMARNAT-2010 standard (SEMARNAT 2010). Ethnobotanical information on the main uses of a plant (in the current case Mexican laurel), and the relationship between users of the plant and those with knowledge about it will enable the importance of the species and its specific uses to be determined and interpreted by local residents in terms that they consider significant (Turner 1988).

Of the 7,800 non-timber species identified in Mexico's cold temperate forests, Mexican laurel is one of the five non-timber forest products considered to have high potential for development (CONABIO 1998). Its uses include medicinal uses, namely infusions for the relief of chest congestion, cough, maladies of the ear, various gastrointestinal diseases, intestinal pain, postpartum uterine contractions, sterility and dysmenorrhea, as well as ceremonial uses (Jiménez-Pérez et al. 2011). In recent years, the plant has been discovered to have properties for treating stress-related conditions (Guzmán-Gutiérrez et al. 2014). As a seasoning, it is sold as bundles of dry leaves together with thyme, marjoram, and oregano, and used to flavor pasta, fish, and tomato sauce dishes (Dávila-Figueroa et al. 2011; Jiménez-Pérez et al. 2011).

While the species is harvested illegally in the ECNP and sold (personal observation and confiscations by environmental authorities), part of the supply is produced legally in two Wildlife Management Units (UMAs in Spanish) in Carboneras, where it is financially supported by SEMARNAT. This study is focused on knowledge about the Mexican laurel and the traditional and domestic uses given to the species. It is the first detailed study of the uses of this plant in Mexico and the first time these uses have been ranked according to the importance they have for the local communities that use them. Given the findings of previous research, it was expected that medicinal uses would prevail in the study area since the communities in the studies are rural. Religious uses were also expected to predominate, especially Easter week festivals, as in other parts of the country. The use of Mexican laurel in Easter celebrations is one of the most studied (López-Gutiérrez et al. 2010; Montañez-Armenta et al. 2011; Ortiz-Quijano 2016). Additionally, this study was carried out in the ECNP, a key area for Mexican laurel production at the national level because of the outstanding organoleptic quality of the plants grown here.

The objectives of the present study were: 1) to evaluate the most important specific traditional uses of the plant among the study communities, based on 


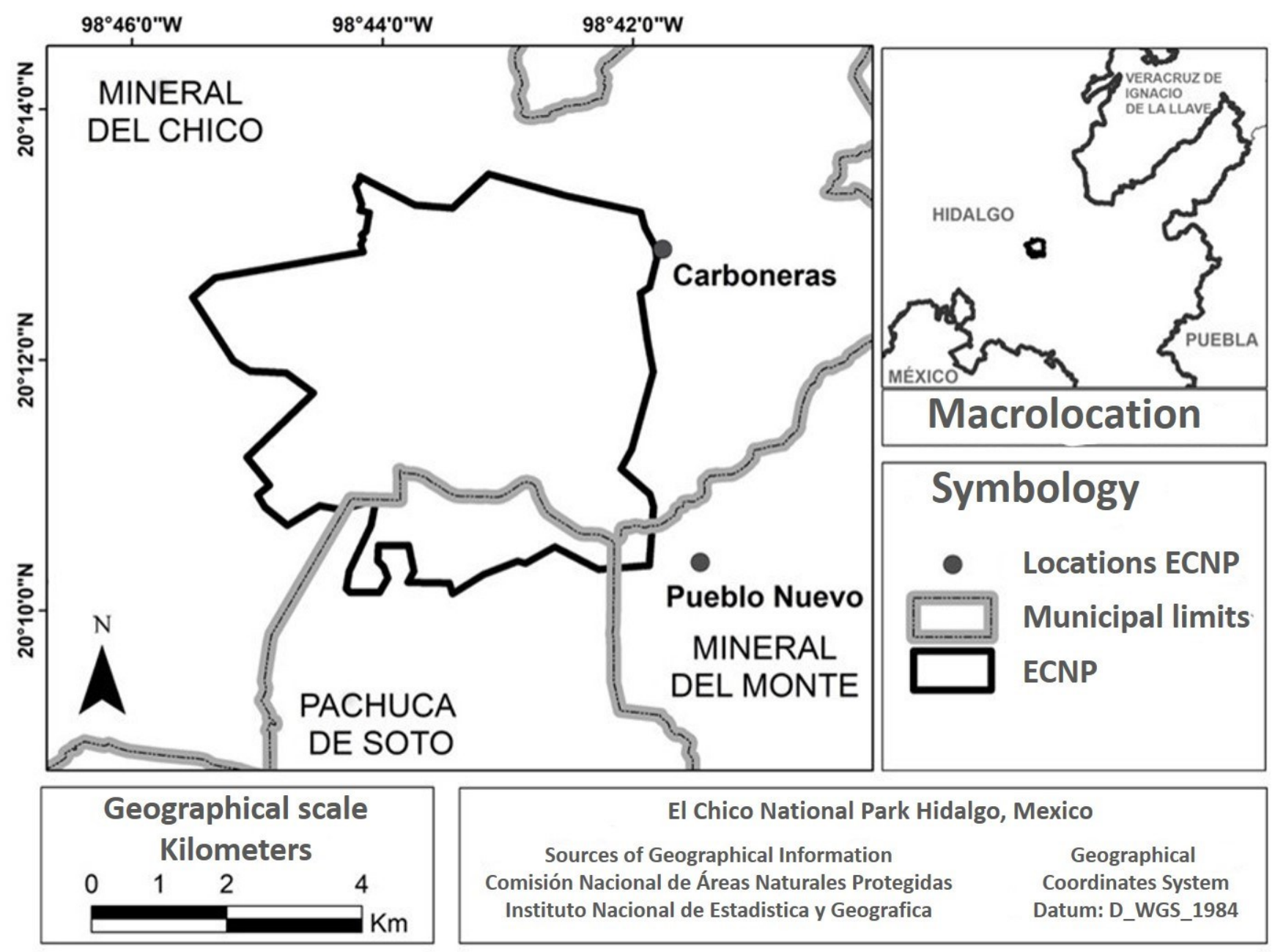

Figure 1 Study locations: Carboneras, Municipality of Mineral del Chico and Pueblo Nuevo, and Municipality of Mineral del Monte, Hidalgo.

the free-listing technique and 2) to analyze the social network among the members of the communities to identify the relationships between the people who are recognized for having some type of knowledge about the uses of the Mexican laurel. The goal is to contribute to documenting the ethnobotanical knowledge on the species, which will be useful both for making management decisions in the context of NPAs and for helping maintain traditional knowledge among the local Mestizo people.

\section{Methods}

Study Area

The ECNP is located in the state of Hidalgo, Mexico, with an area of 2,739 hectares, covered mostly $(62.9 \%)$ by "oyamel" forest, which is where most of the Mexican laurel populations are located. There are seven towns in the ECNP (CONANP 2005; Figure 1), with a total population of 6,721. The local population is of Mestizo origin (INEGI 2010). Ethnobotanical information was collected in Carboneras and Pueblo Nuevo. These two towns are different in age. Carboneras was one of the first communities founded in the region (1876-1897), during a mining boom, and has a population of 1,226 (INEGI 2010). Pueblo Nuevo was founded between 1965-1980 and has a population of 753 (INEGI 2010). It should be noted that the purpose of the study was not to compare them, but to broaden the potential for discovering different uses for the Mexican laurel in the study area.

The main occupations among the male residents are subsistence agricultural production for selfconsumption, mainly in agricultural plots and 
common lands, masonry, and trade, in addition to gardening or factory work in the city of Pachuca. The women are homemakers or domestic employees in Pachuca. Fifty-five percent of the interviewees said they worked at more than one job. Both communities offer tourism services, but none of the respondents make a living in this industry.

Data Collection

Before the fieldwork started, a meeting was held with the authorities of the two towns, to obtain consent for the interviews. A total of 55 interviews were conducted, from May to August 2017. The sample size was determined by the collector's curve (Krebs 1989). This curve gives the number of interviews that are needed to have enough information about the topic under consideration. When the curve stabilizes, it indicates that the universe of the sample is not altered even if more interviews are added (Figure 2). In this case, the collector's curve stabilized at interview 54, leading to the decision to conduct a total of 55 interviews. Thirty interviews were conducted in Carboneras and 25 in Pueblo Nuevo. Twenty-six men and 29 women were interviewed. To ensure anonymity, the interview subjects were identified by initials (Bernard 2006).

The interview subjects were selected using the snowball method (Bernard 2006). The snowball method is initiated by locating a key informant. Subsequently, interviews were continued with the actors named in the snowball process. However, in six cases the subjects did not nominate others, and in other cases they nominated people who had already been interviewed, so it was decided to include six more people who had Mexican laurel in their gardens, yards, or plots of land, under the assumption that they had knowledge about the plant. In addition, 11 young people under 30 years of age were selected to subsequently investigate knowledge transmission. The interviews were divided into three age ranges (15-30, $31-60,>60)$, to represent young people, adults, and seniors. It should be noted that although the actors were interviewed on the basis of previously established methods, they were targeted according to specific characteristics, such as originating from the communities and being of either sex. The interviewers did not seek to interview merchants but rather local users of the plant or people who were mentioned as being related to it according to other actors. While the interviews were conducted with local users of the

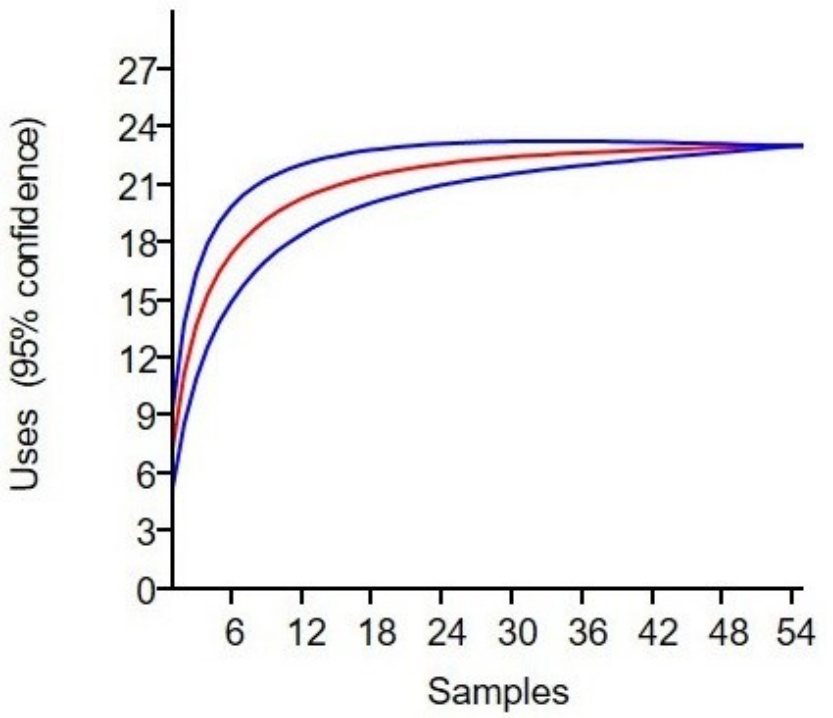

Figure 2 Collector curve. $X$ axis: number of persons interviewed. $Y$ axis: number of uses mentioned.

plants, the method applied could potentially include legal or illegal traders of Mexican laurel, as did happen.

Ethnobotanical information about the Mexican laurel was gathered using a semi-structured interview (Albuquerque et al. 2014; Bernard 2006). The interviewer first asked about the socio-economic characteristics of the interview subject, and then elicited a free-list (Bernard 2006) of the uses given to the laurel and the parts of the plant used for these purposes. At the end of the interview, the subject was also asked about other actors who could potentially provide information about the topic. The free-listing technique consists in listing all the terms mentioned by the actors interviewed on the domain of interest, which are recorded in the order in which they state them. To ensure that the interviewer and the interview subject were talking about the same object, a branch of Mexican laurel was presented as a visual stimulus (Bernard 2006). One hundred percent of the informants recognized the plant.

\section{Data Analysis}

The free-list was analyzed using Smith's salience index by means of the ANTHROPAC 4.0 program (Borgatti 1996). This index assigns the highest values, close to one, according to the frequency and order by which the terms are mentioned in the list. It enables them to be classified by their importance. Notable breaks or discontinuities occur between the numerical 
values of the elements with greater or lesser salience (Gravlee 2002).

Based on the results of the free-list analysis, multidimensional scaling (MDS) was applied based on the Jaccard index, using the PAST 3.0 program (Hammer et al. 2001). This locates the different uses in a hyperdimensional space as a function of their similarity according to the number of times they are mentioned (Romney and Weller 1984). The uses of Mexican laurel reported in the interviews were classified into four categories modified from Castañeda and Albán (2016) as follows: seasoning, used to add flavor and aroma to various dishes; medicinal, used to treat or prevent diseases; cultural, used in social or ritual activities; and craft production, in which the seed is used for manufacturing items by hand.

Information provided by informants about other members of the community was noted, graphed, and analyzed using the UCINET 6.403 and NETDRAW 2.120 programs (Borgatti 2002), which allowed us to draw a social network of the actors. This network shows that the greater the number of mentions of a given actor by other members of the network, then the greater the recognition of that actor in the social group with respect to a particular topic (Laumann and Pappi 1973). Each actor is represented by a symbol whose size represents the degree of recognition that other actors assign them. The lines that join the actors of the network can be uni- or bi-directional; that is, nomination may or may not be reciprocal. Disconnected nodes in the network represent people who were not mentioned by other actors.

\section{Results}

Uses of Mexican Laurel in Communities in the ECNP

Of the actors interviewed from the study communities, $100 \%$ acknowledged that the plant was used in their homes. The use most mentioned was seasoning (95\%); $53 \%$ mentioned cultural uses, $42 \%$ mentioned medicinal uses, and only $2 \%$ of those interviewed mentioned crafts. These results contrast with those given by the quantitative analysis of the Smith index. Simultaneously taking into account both the order in which a use is mentioned, as well as the frequency, it enables the uses, in this case from a local perspective, to be ranked more precisely. This is the case of cultural uses. Although they were mentioned by more than half of the actors (53\%), they were often named near the end of the free-list, and the interview often had to be focused (Bernard 2006) before the actors could identify, remember, and mention these uses.

The actors mentioned 25 specific uses of the Mexican laurel, from which the Smith index was calculated. Five groups could be registered in the freelist, identified by gaps or breaks in the value of the index. Use of the plant for pickling chile peppers had the highest value (0.655), indicating that it has the greatest importance in the study localities. The second break is between the use of the laurel in foods based on tomato sauce (0.364), fish (0.351), pasta (0.296), and chicken broth (0.265), suggesting that these are also important uses. Less important were its uses for mixiotes (0.210), tinga (0.192), and mole (0.186), as well as medicinal use for teas $(0.200)$ shown by the third break. The first three groups are made up of culinary uses, while the first medicinal use does not emerge until after the third break. The fourth break is between medicinal use in baths to cure espanto and remove bad energy (0.179), as well as postpartum baths (0.176) and in dishes such as picadillo (0.165) and pozole (0.152). The other 12 specific uses in the final group were mentioned infrequently, and in last place on the free-list, indicating that they are not very important in these communities. Among these uses are the seven religious uses that are made of the plant in the study communities (Table 1).

The multidimensional scaling diagram (MDS) grouped the uses of the Mexican laurel according to the greater frequency of mentions and the similarity of the answers among the interviewees who mentioned them. In this case, the uses as seasoning were grouped together, confirming the importance of the species in this category rather than for medicinal or cultural uses (Figure 3).

\section{Social Network of Knowledge and Uses of Mexican Laurel}

The social network identified two individuals with specialized knowledge of the Mexican laurel in Carboneras and showed that there is a relationship between the informants. The network was made up of the 55 interview subjects. These actors named at least one other person and up to seven (with the exception of the six actors who did not name anyone else), making up the network of relationships between persons who use or know the species in the study localities. The disconnected nodes (15) in the network correspond to people who have some relationship or knowledge about the plant because they have the plant growing in their garden, backyard, or plot of 


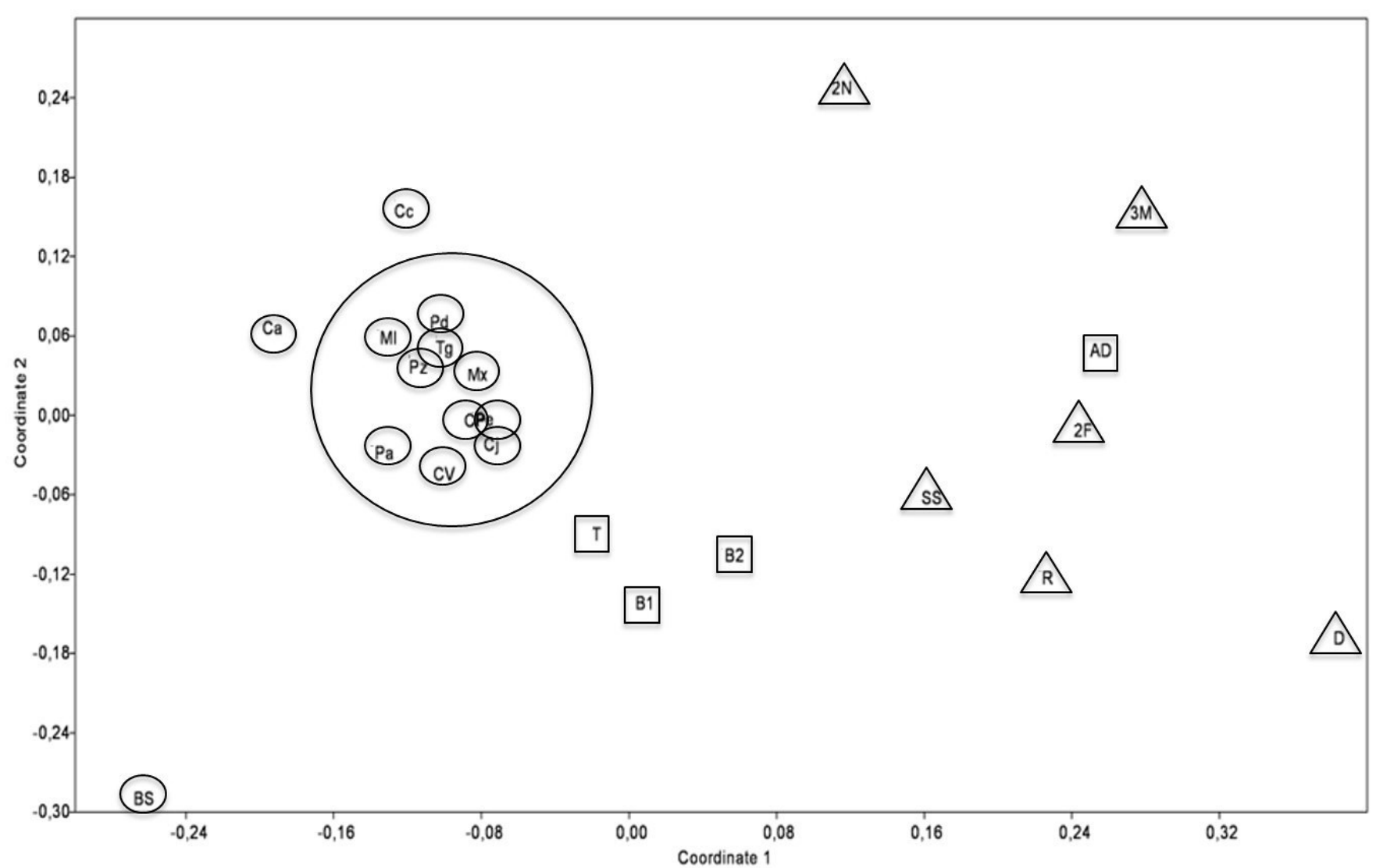

Figure 3 Diagram of multidimensional scaling (MDS) of reported uses of Mexican laurel. Each point represents one use: circles = seasoning, triangles = cultural, and squares = medicinal. Use in the December 12 festival and as material for handicrafts was not included in the MDS, since they behave as outliers. The meaning of the symbols are found in Table 1.

land although they were not necessarily mentioned by other actors, in addition to some young people not taken into account by seniors and vice versa (Figure 4). The network shows mainly unidirectional relationships; that is, recognition between actors is not always reciprocal. It also demonstrates that there is a relationship between actors in Pueblo Nuevo and in Carboneras. The social network shows a concentration around the actor BBM, who was mentioned by 16 others. This person was the central interviewee of the network, and was followed by the actor VMG, with nine mentions and GFO and PVP with eight mentions each. It should be noted that $\mathrm{BBM}$ and VMG are recognized in both towns as experts on the Mexican laurel in Carboneras, as they are the promoters of the two UMAs. These actors, were the only ones identified as trading in Mexican laurel. In general, the actors with the highest number of mentions were identified as having some relationship with the Mexican laurel tree and, therefore, according to the interview subjects, had the most knowledge about the plant.

It is notable that of the 40 connected actors in the network, 20 were women and 20 were men, which indicates that both genders have knowledge about the uses of the plant. Adults were the age group most mentioned in the social network (19), followed by seniors (13) and eight young people. Young people, despite being mentioned less than other age groups, are already identified by other actors as knowing about the plant.

\section{Discussion}

\section{Local Uses of Mexican Laurel}

This is the first study focused on investigating the specific uses of Litsea glancescens in Mexico, specifically in the ECNP. The quantitative results showed that its uses as a seasoning are the most common and most important $(95 \%)$ in the ECNP, while medicinal and 


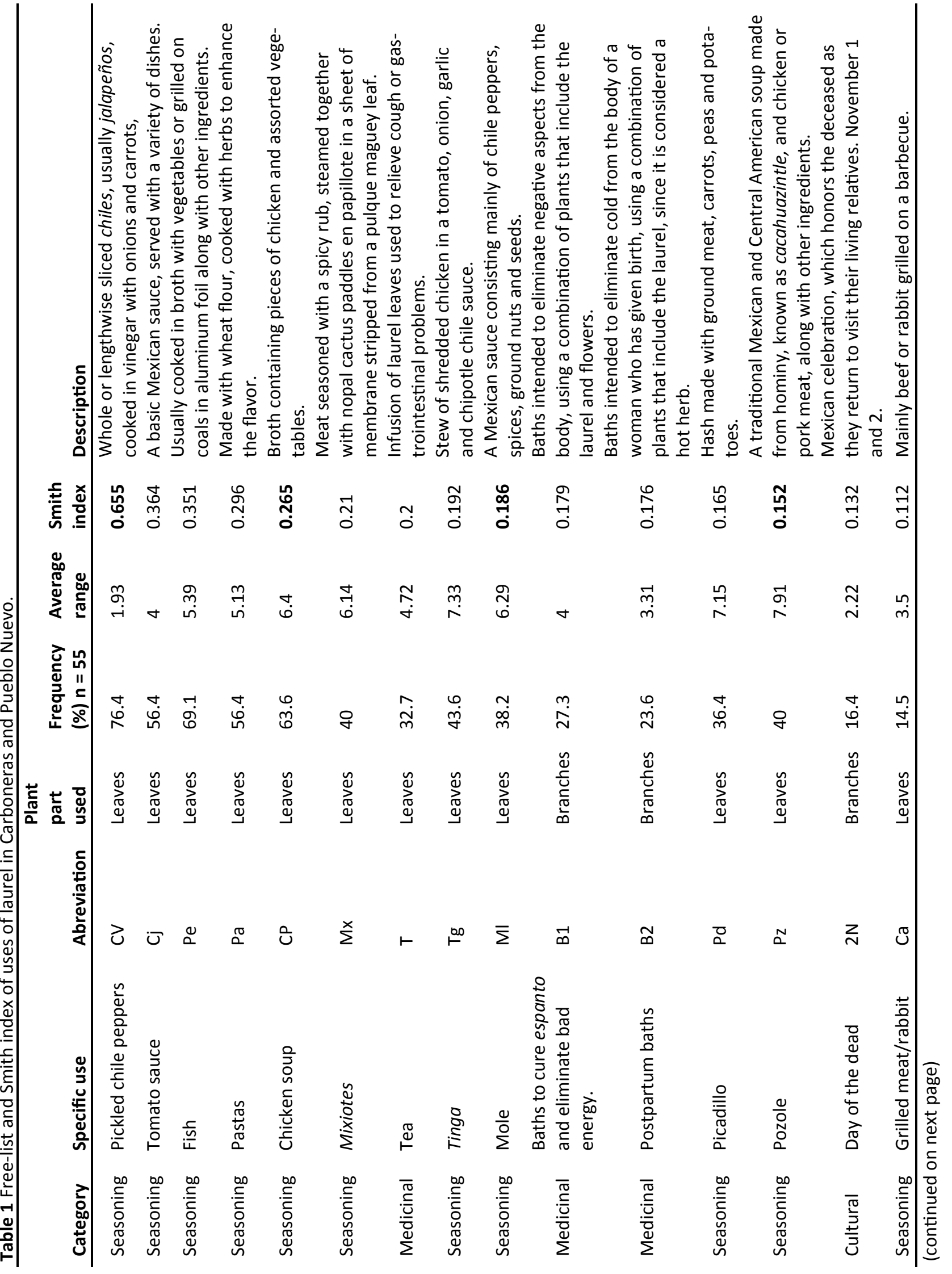




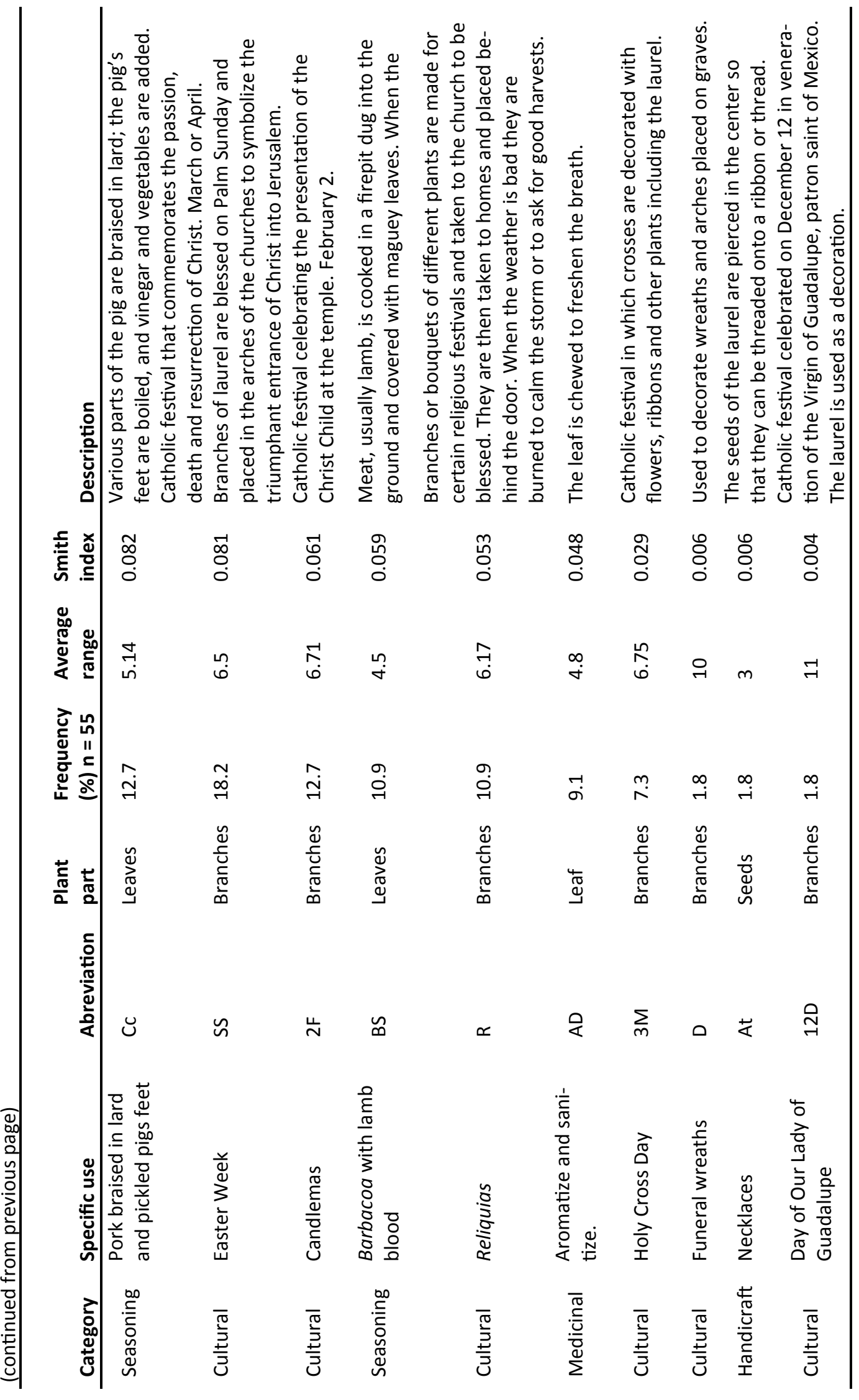




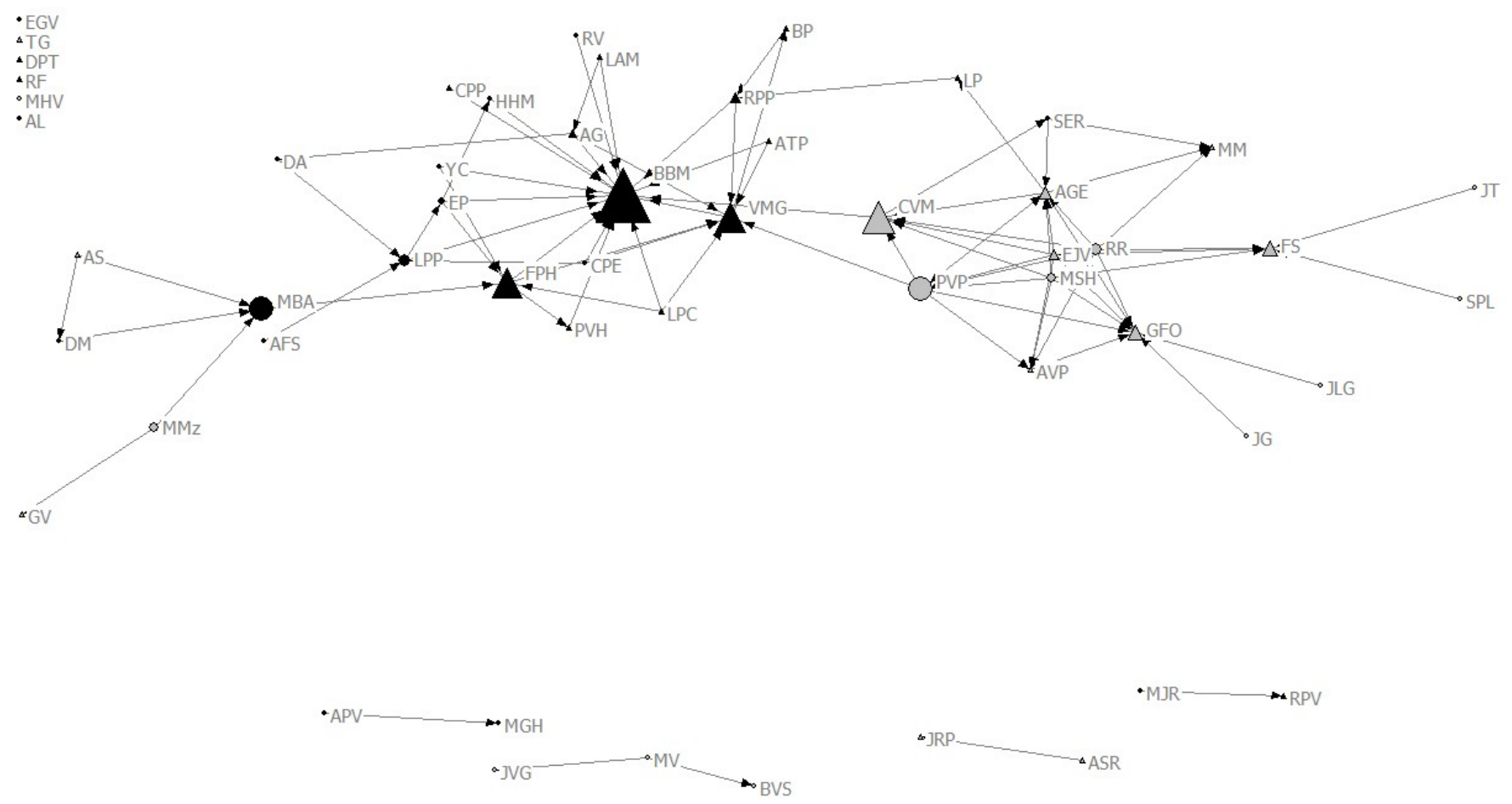

Figure 4 Social network of knowledge about uses of Mexican laurel in Carboneras (black) and Pueblo Nuevo (gray). Gender: triangle $=$ male and circle $=$ female. The size represents the importance of the actor in the study community with respect to the actor's knowledge of the study species.

religious uses have medium and low importance, respectively, among this social group. This suggests that in the study area, its use as seasoning is the most frequent but also the first to be mentioned by the interview subjects, which could be due to the fact that the Mexican laurel plays a part in satisfying basic human needs through its use in food (Castañeda and Albán 2016), an aspect that supports the idea that food is a cultural element that tends to be strongly maintained.

The results again show that religious uses of the Mexican laurel are of less relative importance. This result suggests that there may be a lack of interest among the population regarding certain cultural practices, or specifically an influence from other religious practices in which the use of particular elements from nature is not as important (OrtizQuijano 2016). These results contrast markedly with other ethnobotanical studies that found religious uses during Easter week to be among the main uses of Mexican laurel. This is the only use described in detail in the ethnobotanical literature (López-Gutiérrez et al. 2010; Montañez-Armenta et al. 2011; Ortiz-Quijano
2016) and in some cases there is even a bias toward investigation of religious uses for this species.

In our study, $47 \%$ of the actors interviewed did not mention religious uses of the plant. However, our results showed that religious uses are the least important from the viewpoint of the local people, even though there are seven religious uses recorded for the ECNP, which is $28 \%$ of the total number of uses. It should be noted that although, as already mentioned, the Mexican laurel is used in Palm Sunday celebrations, its final use is as a culinary seasoning, since the branches are subsequently taken home, stored, and used in the kitchen (field observation).

On the other hand, it is notable that the plant is indeed harvested for this purpose not far from the ECNP $(13 \mathrm{~km})$. This is for the Cabalgata laurelera (the mounted procession of the laurels held annually for more than 100 years), which sets out from Nopaltepec (State of Mexico) and rides to Tezoantla, Hidalgo (López-Gutiérrez et al. 2010). In this particular instance, the plant plays an important role in this Easter week festival, and approximately $120 \mathrm{~kg}$ of Mexican laurel was harvested at 2017 for this 
celebration (field observation). However, it should be noted that there is no comparison between the amount harvested for this festival and the amount confiscated, which was up to $1,200 \mathrm{~kg}$ per occasion, harvested for sale in Mexico City (Exp. PFPA/20.3/8C.17.5/0001-17. Procuraduría Federal de Protección al Ambiente, Delegación Hidalgo). It is clear that the pressure on the species is related to illegal harvesting for trade, while harvesting for Easter week is not an important threat in the ECNP. These facts lead us to reject the hypothesis (proposed in this study) that medicinal uses would prevail in the study area since the communities in the studies are rural. Religious uses were also expected to predominate, especially Easter week festivals, as in other parts of the country. In contrast, the uses as a seasoning were the most common and most important in the study area, while medicinal and religious uses had a marginal importance, according to the quantitative approach applied.

Medicinal uses had an intermediate level of importance in this study, which would seem to contradict the results of other studies on the use of these plants. Previous studies recorded that while indigenous communities use them as sustenance, their medicinal use is more important for Mestizo communities (Beltrán-Rodríguez et al. 2014). Our results could be due to the fact that the laurel is not seen as a food in itself. Moreover, since the study communities are relatively close to the Hidalgo state capital, the residents have access to other health care services. The use of Mexican laurel seeds to make handcrafted necklaces is recorded for the first time in this study; however, this use is rare among the people surveyed, and the necklaces are not produced for sale.

The food uses of Mexican laurel are seen as the most important for the study communities. Given this, the people of Carboneras and Pueblo Nuevo should be the main promoters of plant conservation, since it is not only a local species but one that is central to their way of life, especially through food. Including local knowledge will enable the generation of techniques for the management and sustainable use of the plant (Blancas et al. 2013). Specifically, the UMA owners are locally recognized as the main actors in the management of the Mexican laurel, so they could lead in the implementation of local and federal conservation strategies, interventions, and conservation based on communities and local rules according to the needs of the people for pursuing their livelihoods (Berkes 2007). In Tehuacán Valley, there are people authorized to harvest the leaves, branches, or trees of the Mexican laurel, while those who break this rule are fined (Blancas et al. 2013). Practices and communal regulations of this type are imperative in ECNP to guarantee sustainable use of the species.

\section{Implications of the Social Network.}

The importance of the research methods used is also reflected in the structuring of the social network of people involved with the species. They can be identified as those who know about its uses. It can be seen clearly that the actors who received the highest number of mentions were the two people (BBM and $\mathrm{VMG}$ ) who are responsible for the UMAs dedicated to the production of laurel. This suggests that the people who directly manage the species are most widely recognized by the other members of this social group, probably because they are closer to the plant. The network also showed that local authorities were mentioned, which suggests that people identify them as having greater access to information about local resources because they are authorities (Reyes-García et al. 2008), or, as in this case, because they are the ones authorized to provide this information. This shows that these actors play different critical roles in the network and this is why they stand out from the other actors (Mesquita 2008).

The social network also identifies a relationship between the two villages, which could be due to their proximity and to the high degree of kinship among residents, as well as to similar socioeconomic characteristics.

It should be noted that in addition to the fact that there were people who did not nominate anyone else during the interviews, some of the actors were also reluctant to provide information on uses of the plant. This is one of the problems that can arise when social phenomena are investigated using the snowball method (Biernacki and Waldorf 1981). In this case, it relates to a study of a plant which people are not willing to talk about, as was also the case of Montañez -Armenta et al. (2011) in their study of the Mexican laurel in Aguascalientes.

People in the study communities identified restrictions on the use of Mexican laurel, a species in danger of extinction. They are aware of supervision of the species promoted by National Park officials, known to local people as los verdes (the greens) and the 
federal officials, known as los azules (the blues). Although prior data indicated that there are actors involved in illegal sales of Mexican laurel (field observation), these were not reported by any of the informants; people only talked about others who dealt with the plant legally, through its production in the UMAs. It should be added that there was little time to build rapport in each interview (Bernard 2006).

It is necessary to highlight the difference between lists of uses of a given plant (or lists of useful plants) — widely used in ethnobotany - and the results obtained through quantitative tools, particularly because methodological rigor is necessary to make contributions to science (Phillips and Gentry 1993). A list of uses alone does not make it clear which are more used or whether the uses are current or not. Sometimes distinguishing the latter is not the objective and therefore a simple list is a valuable technique. In contrast, quantitative tools such as the Smith index order the uses in a natural way, suggesting the importance that they have in the ways of life of a specific social group (Morais et al. 2009).

With the Smith index, the uses cited with greater frequency and those that are mentioned first indicate what is most present in their memory and what is most significant, because it is what they currently use or because it is most important to them (Morais et al. 2009). The items located at the end of the list are the least remembered, which shows that they are not as important as the ones that are mentioned earlier, and they might even not be current uses. It may mean that they were probably important for people in the past, but are no longer, so it takes the actors longer to remember them, because they may be in disuse.

\section{Conclusions}

This study shows the importance of the uses of Mexican laurel and enabled the persons involved with these uses and possessing knowledge about the plant to be identified. The social network shows the relationship between members of the study communities, not only among the members of a single community but also between members of the two communities. The network diagram also shows the actors who are clearly identified as having some relationship with the plant, among them the owners of UMAs or actors with some authority in the communities, whom the people identify as those with access to information. The uses of Mexican laurel as a seasoning stand out in this study, which agrees with studies where it is given great importance because it is a traditional seasoning typically used in Mexican cuisine. This is different from other regions, where its uses for religion and traditional medicine are reported as more important. Even so, it can be observed that the communities around the national park make use of this species and it is part of their daily life.

\section{Acknowledgments}

The authors thank the residents and authorities of the communities of Carboneras, Mineral del Chico, Pueblo Nuevo, Mineral del Monte, for the information they provided, as well as María del Consuelo Cuevas Cardona and Adriana Gómez Aiza for their valuable comments.

\section{Declarations}

Permissions: None declared.

Sources of funding: This study was supported by CONACyT through the PhD scholarship of the first author (No. 594488), and by CONACyT project CB271837, 280901, 293914, through the "Red Temática de Productos Forestales no Maderables: Aportes desde la etnobiología para su aprovechamiento sostenible".

Conflicts of Interest: None declared.

\section{References Cited}

Alburquerque, U. P., T. A. de Sousa Araújo, M. A. Ramos, V. T. do Nascimento, R. F. P. de Lucena, J. M. Monteiro, N. L. Alencar, and E. de Lima Araújo. 2009. How Ethnobotany Can Aid Biodiversity Conservation: Reflections on Investigations in the Semi-Arid Region of NE Brazil. Biodiversity and Conservation 18:127-150. DOI:10.1007/s10531-0089463-8.

Alburquerque, U. P., L. V. F. C. Cunha, R. F. P. Lucena, and R. R. N. Alves. 2014. Methods and Techniques in Ethnobiology and Ethnoecology. Springer, New York.

Alexiades, M., and P. Shanley. 2004. Productos Forestales, Medios de Subsistencia y Conservación. Estudios de Caso sobre Sistemas de Manejo de Productos no Maderables. Centro para la Investigación Forestal Internacional, Jakarta, Indonesia.

Beltrán-Rodríguez, L., A. Ortiz-Sánchez, N. A. Mariano, B. Maldonado-Almanza, and V. ReyesGarcía. 2014. Factors Affecting Ethnobotanical Knowledge in a Mestizo Community of the Sierra de Huautla Biosphere Reserve, Mexico. Journal of Ethnobiology and Ethnomedicine 10:14. DOI:10.1186/1746-4269-10-14. 
Berkes, F. 2007. Community-based Conservation in a Globalized World. Proceedings of the National Academy of Sciences of the United States of America 104:1518815193. DOI:10.1073/pnas.0702098104.

Bernard, R. H. 2006. Research Methods in Anthropology: Qualitative and Quantitative Approaches, $4^{\text {th }}$ edition. Altamira Press, New York.

Biernacki, P., and D. Waldorf. 1981. Snowball Sampling, Problems and Techniques of Chain Referral Sampling. Sociological Methods and Research 10:141-163. DOI:10.1177/004912418101000205.

Blancas J., A. Casas, D. Pérez, J. Caballero, and E. Vega. 2013. Ecological and Socio-cultural Factors Influencing Plant Management in Náhuatl Communities of the Tehuacán Valley, Mexico. Journal of Ethnobiology and Ethnomedicine 9:39. DOI:10.1186/1746-4269-9-39.

Borgatti, S. P. 1996. ANTHROPAC 4.0 Methods Guide. Analytic Technologies, Natick, MA.

Borgatti, S. P. 2002. Netdraw Network Visualization. Analytic Technologies, Harvard, MA. Available at: http: / / www.analytictech.com / ucinet / download.htm. Accessed on October 29, 2017.

Boster, J. S., J. C. Johnson, and S. C. Weller. 1987. Social Position and Shared Knowledge: Actors' Perceptions of Status, Role, and Social Structure. Social Networks 9:375-387. DOI:10.1016/0378-8733 (87)90005-0.

Castañeda, R., and J. Albán. 2016. Importancia Cultural de la Flora Silvestre del Distrito de Pamparomás, Ancash, Perú. Ecología Aplicada 15:151 -169. DOI:10.21704/ rea.v15i2.755.

CONABIO (Comisión Nacional para el Conocimiento y Uso de la Biodiversidad). 1998. La Diversidad Biológica de México: Estudio de País. Comisión Nacional para la Biodiversidad, Ciudad de México, Mexico.

CONANP (Comisión Nacional de Áreas Naturales Protegidas). 2005. Programa de Conservación y Manejo Parque Nacional el Chico. Comisión de Áreas Naturales Protegidas, Pachuca de Soto, Hidalgo, Mexico.

Dávila-Figueroa, C. A., F. J. Flores Tena, F. M. Domínguez, R. C. Tapia, and E. P. Molphe Balch. 2011. Estatus Poblacional y Niveles de Aprovechamiento del Laurel Silvestre (Litsea glaucescens) en Aguascalientes. Revista Mexicana de Ciencias Forestales 4:47-59.
Gómez-Pompa, A. 2001. Etnobotánica y Conservación. Revista de Geografía Agrícola 31:9-15.

Gaoue, O. G., M. A. Coe, M. Bond, G. Hart, B. C. Seyler, and H. McMillen. 2017. Theories and Major Hypotheses in Ethnobotany. Economic Botany 71:269 -287. DOI:10.1007/s12231-017-9389-8.

Gravlee, L. 2002. The Uses and Limitations of Free Listing in Ethnographic Research. Research Methods in Cognitive Anthropology [web page]. Available at: http://www.gravlee.org/ang6930/ freelists.htm\#comp. Accessed on September 02, 2018.

Guzmán-Gutiérrez, S. L., R. Reyes-Chilpa, and H. Bonilla-Jaime. 2014. Medicinal Plants for the Treatment of "Nervios", Anxiety and Depression in Mexican Traditional Medicine. Revista Brasileira de Farmacognosia 24:591-608.

DOI:10.1016/j.bjp.2014.10.007.

Hammer, O., D. A. Harper, and P. D. Ryan. 2001. PAST: Paleontological Statistics Software Package for Education and data Analysis. Paleontología Electrónica 4:9. Available at: http://www.palaeoelectronica.org/2001_1/past/issue1_01.htm. Accessed on October 30, 2017.

INEGI (Instituto Nacional de Estadística y Geografía). 2010. Censo General de Población y Vivienda 2010. Tabulados, población total. Instituto Nacional de Estadística y Geografía, Ciudad de Mexico, Mexico. Available at: http://www.inegi.org.mx/sistemas/ TabuladosBasicos/Default.aspx?c $=27302$. Accessed on October 18, 2017.

Jiménez-Pérez, N.C., F.G. Lorea Hernández, C. Jankowski, and R. Reyes-Chilpa. 2011. Essential Oils in Mexican Bays (Litsea spp., Lauraceae): Taxonomic Assortment and Ethnobotanical Implications. Economic Botany 65:178-189. DOI:10.1007/s12231-011-9160-5.

Krebs, C. J. 1989. Ecological Methodology. Harper and Row, New York.

Laumann, E. O., and F. U. Pappi. 1973. New Directions in the Study of Community Elites. American Sociological Review 38:212-230. DOI:10.2307/2094396.

López-Gutiérrez, B. M., B. E. Pérez-Escandón, and M. A. Villavicencio-Nieto. 2010. Los Laureleros de Nopaltepec, Estado de México y el Uso de Litsea glaucenscens H.E.K. (Lauraceae) de Tezoantla, Estado de Hidalgo, México. 1er Encuentro HispanoPortugués de Etnobiología (EHPE 2010): Los 
Desafíos de la Etnobiología en España y Portugal. Revista de Fitoterapia 10 (S1).

López-Gutiérrez, B. M., B. E. Pérez-Escandón, and M. A. Villavicencio-Nieto. 2014. Aprovechamiento Sostenible y Conservación de Plantas Medicinales en Cantarranas, Huehuetla, Hidalgo, México, Como un Medio para Mejorar la Calidad de Vida en la Comunidad. Botanical Sciences 93:389-404. DOI:10.17129/botsci.106.

Mesquita, R. B., F. L. Pinheiro Landim, P. M. Collares, and C. Gilvaní de Luna. 2008. Analysis of Informal Social Networks: Application to the Reality of Inclusive School. Interface - Comunicação, Saúde, Educação 12:549-562. DOI:10.1590/S141432832008000300008.

Montañez-Armenta, M., T. E. Medina, and S. Martín. 2011. Aprovechamiento Tradicional de una Especie Protegida (Litsea glaucescens Kunth) en "Sierra del Laurel", Aguascalientes, México. Ra Ximbai 2:155172. Available at: http://www.redalyc.org/ articulo.oa?id=46119239001. Accessed on February 09, 2018.

Morais, F. F. de, R. F. de Morais, and C. J. da Silva. 2009. Traditional Ecological Knowledge about Plants Cultivated by Fishermen at Community Estirao Comprido, Pantanal Matogrossense, Brazil. Boletim do Museo Parense Emilio Goeldi. Ciências Humanas 4:277-294. DOI:10.1590/S198181222009000200005.

Ortiz-Quijano, D. E. 2016. La Pasión de Tezontepec. Tradición, Cultural e Identidad. Monografía Histórica de la Festividad de Semana Santa en Terontepec de Aldama Hidalgo. Secretaría de Cultura del Estado de Hidalgo, Pachuca de Soto, Hidalgo, México.

Pardo de Santayana, M., and E. Gómez Pellón. 2003. Etnobotánica: Aprovechamiento Tradicional de Plantas y Patrimonio Cultural. Anales del Jardín Botánico de Madrid 60:171-182. Available at: http:// www.redalyc.org/articulo.oa? id $=55660112$. Accessed on March 03, 2018.

Pío-León, J. F., F. Delgado-Vargas, B. MurilloAmador, J. L. León-de-la-Luz, R. Vega-Aviña, A. Nieto-Garibay, M. Córdoba-Matson, and A. Ortega -Rubio. 2017. Environmental Traditional Knowledge in a Natural Protected Area as the Basis for Management and Conservation Policies. Journal of Environmental Management 201:63-71. DOI:10.1016/j.jenvman.2017.06.032.
Phillips, O., and A. H. Gentry. 1993. The Useful Plants of Tambopata, Peru II: Additional Hypotheses Testing in Quantitative Ethnobotany. Economic Botany 47:33-43. DOI:10.1007/ BF02862204.

Pulido, M. T., and C. Cuevas-Cardona. Cactus Nurseries and Conservation in a Biosphere Reserve in Mexico. Ethnobiology Letters 4:96-104. DOI:10.14237/ebl.4.2013.58.

Reyes-García, V., J. L. Molina, J. Broesch, L. Calvet, T. Huanca, J. Saus, S. Tanner, W. R. Leonard, T. W. McDade, and TAPS Bolivian Study Team. 2008. Do the Aged and Knowledgeable Men Enjoy More Prestige? A Test of Predictions from the Prestigebias Model of Cultural Transmission. Evolution and Human Behavior 29:275-281 DOI:10.1016/ j.evolhumbehav.2008.02.002.

Romney, A. K., and S. C. Weller. 1984. Predicting Informant Accuracy from Patterns of Recall Among Individuals. Social Networks 6:59-77. DOI:10.1016/0378-8733(84)90004-2.

SEMARNAT (Secretaria de Medio Ambiente y Recursos Naturales). 2010. Norma Oficial Mexicana NOM-059-SEMARNAT-2010, Protección Ambiental Especies Nativas de México de Flora y Fauna Silvestres Categorías de Riesgo y Especificaciones para su Inclusión, Exclusión o Cambio -Lista de Especies en Riesgo, Diario Oficial de la Federación 30 de diciembre de 2010. Secretaria de Medio Ambiente y Recursos Naturales, Mexico City, Mexico. Available at: http://www.dof.gob.mx/nota_detalle_popup.php? codigo $=5173091$. Accessed on September 17, 2018.

Shrestha, S., and K. E. Medley. 2017. Integrating Ecological and Ethnobotanical Knowledge to Promote Collaborative Conservation Planning in the Nepal Himalaya. Mountain Research and Development 37:97-107. DOI:10.1659/MRDJOURNAL-D-15-00081.1.

Turner, N. J. 1988. The Importance of a Rose: Evaluating the Cultural Significance of Plants in Thompson and Lillooet Interior Salish. American Anthropologist 90:272-290. DOI:10.1525/ aa.1988.90.2.02a00020.

Tuxill, J., and G. P. Nabhan. 2001. People, Plants and Protected Areas: A Guide to in situ Management. Sterling, London. 